УДК 638.121.2

(C) 2012

Шамро Л. П., старший науковий співробітник,

Шамро Т. М., інженер

Національний науковий центр «Інститут бджільництва ім. П. І. Прокоповича»

\title{
ВІКОВІ ЗМІНИ БІОЛОГІЧНИХ ОСОБЛИВОСТЕЙ РОБОЧИХ БДЖІЛ
}

\section{Рецензент - кандидат сільськогосподарських наук Г. М. Гречка}

Досліджено вікові зміни вмісту білка в гемолімфі робочих бджіл, ступенів розвитку їх глоткових залоз і жирового тіла. В результаті изього встановлено, щяо потенційний запас білка в гемолімфі бджіл передосінньої генерації з віком не знижується так як у ранньо-літніх, а залишається на досить стабільному рівні. В иеей період у бджіл зростають ступінь розвитку глоткових залоз $i$ жирового тіла та досягають 3,56 і 2,65 балів відповідно, щзо є характерним для них під час підготовки до зимового періоду та його перебігу.

Ключові слова: гемолімфа, глоткові залози, жирове тіло, робочі бджоли.

Постановка проблеми. У зв'язку зі змінами природно-кліматичних умов (часті тривалі посухи під час пасічницького сезону), збідненням кормової бази для бджіл через зменшення посівних площ медоносних культур, із погіршенням екологічної обстановки вивчення анатомофізіологічних показників бджіл має важливе наукове значення.

Аналіз основних досліджень і публікацій, у яких започатковано розв'язання проблеми. Гемолімфа бджоли складає внутрішнє середовище їі організму. Частково вона проходить судинами, а далі вільно виливається в порожнину й омиває всі внутрішні органи, тканини та клітини тіла. Вона поставляє їм необхідні поживні речовини й, водночас, із організму бджоли в неї переходять продукти обміну. Тобто, $з$ гемолімфою бджоли безпосередньо пов'язані всі основні процеси обміну речовин у іiі організмі $[1,6,9]$. Тому всі зміни, що в ньому проходять, як правило, позначаються на білковій картині гемолімфи $[2,4]$.

Вміст білка в гемолімфі більш постійний у дорослих бджіл, - він значно змінюється в залежності від сезону, а найвищі його значення відмічені в бджіл восени та взимку [10]. За даними I. О. Левченка, вміст білка в гемолімфі робочих бджіл $є$ величиною лабільною й залежить від багатьох факторів, із яких найбільш важливе значення має рівень білкового харчування, а також фізіологічний стан і пов'язана 3 ним функціональна активність бджіл [7]. У гемолімфі бджіл, хворих на вароатоз, вміст білка знижується в 1,6-2,3 рази (на 39,2-57,1 \%) [3, 7]. Це впливає на розвиток глоткових залоз - життєво важливих органів бджоли, що відповідають за інвертування цукрів і вироблення маточного молочка, а також жирового тіла, в якому накопичуються поживні речовини в їі організмі.

Мета досліджень та методика їх проведення. Мета досліджень - вивчення анатомофізіологічних показників у бджіл.

Дослідження проведені на базі племінної пасіки 3 розведення бджіл української степової породи Гадяцького відділення ННЦ ІБдж.

Вміст білка в гемолімфі бджіл визначали періодично впродовж червня та серпня, починаючи зі щойно народжених, а потім - у особин 5-, 10-, 15-, 20-, 25- та 30-денного віку. Відібраних із сім’ї бджіл розміщували в лабораторні ентомологічні садки по 15-20 штук і транспортували в лабораторію, де проводили в них відбір гемолімфи й готували препарати для дослідження глоткових залоз і жирового тіла. Концентрацію білка в гемолімфі бджіл визначали за допомогою біуретового методу [5]. Морфологічний стан глоткових залоз, жирового тіла вивчали за методикою А. Мауріціо [8].

Результати досліджень. Визначено, що динаміка зміни вмісту білка в гемолімфі бджіл різних генерацій дещо відрізняється (рис.1).

Так, у червні вміст білка вищий у бджіл із 5-го по 20-й день їхнього життя, а в щойно народжених і льотних (вік 25-30 днів) - нижчий. Концентрація білка в гемолімфі різновікових бджіл передосінньої генерації дещо стабільніша, її показники, порівняно 3 ранньо-літньою генерацією, вищі.

Відомо, що в здорових бджіл за нормальних умов утримання сім'ї, починаючи 3 чотирьохпятиденного віку, розвиваються глоткові залози, й такі бджоли стають годувальницями розплоду, що також наочно представлено на рис. 2. В цей час вони посилено споживають білковий корм, що й зумовлює підвищення рівня білка в їх гемолімфі [7]. 


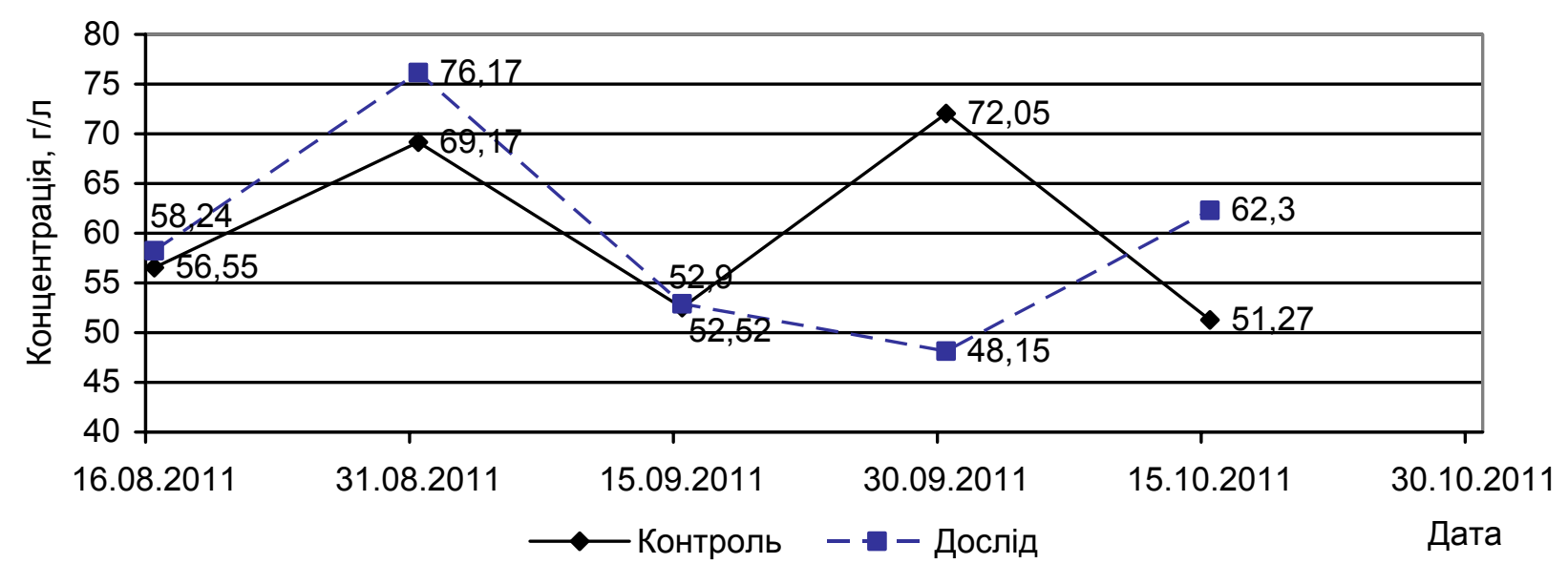

Рис. 1. Концентрація білка в гемолімфі бджіл, г/л

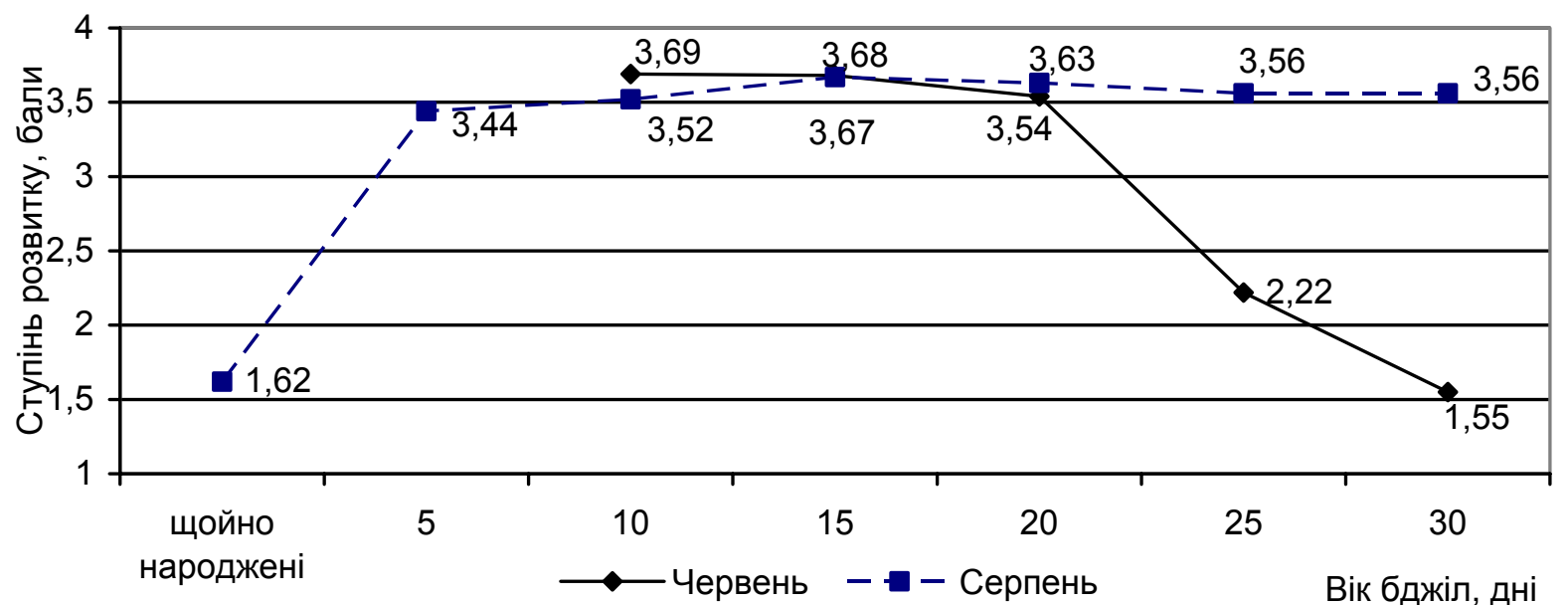

Рис. 2. Ступінь розвитку глоткових залоз у бджіл

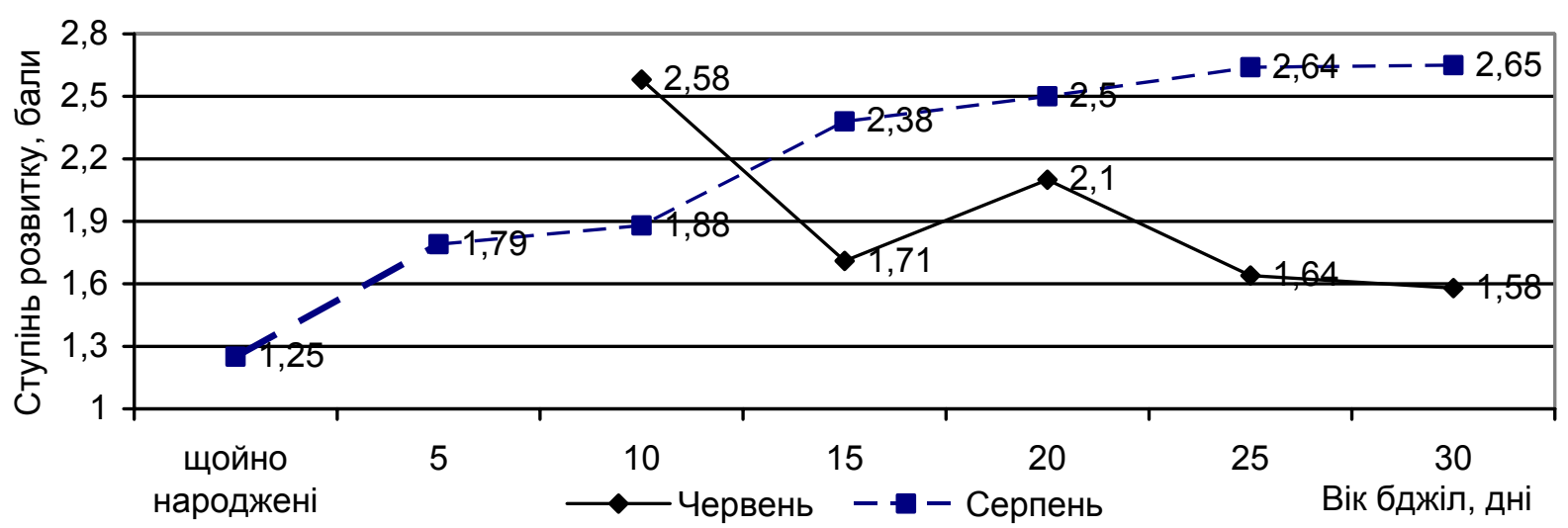

Рис. 3. Ступінь розвитку жирового тіла в бджіл

Iз рисунка 2 видно, що, починаючи 3 десятогодванадцятого дня, життя бджіл ранньо-літньої генерації, ступінь розвитку їх глоткових залоз поступово зменшується. Робочі бджоли з віком перестають вигодовувати розплід і переключаються на виконання інших робіт, що не потребують функціонування цих залоз, а в серпневих бджіл глоткові залози досягли 3,56 балу свого розвитку в п'ятиденному віці й надалі постійно знаходилися в такому розвиненому стані до тридцятого дня життя.

Жирове тіло в бджіл виконує різні функції в організмі, пов'язані 3 відкладанням резервних речовин, виділенням кінцевих продуктів обміну 
й відіграє суттєву роль в нормалізації їх фізіологічного стану. Як відомо, жировому тілу належить істотне значення в процесі підготовки бджіл до зими.

Ступінь розвитку жирового тіла в різновікових бджіл ранньо-літньої та серпневої генерацій дещо різниться (рис. 3).

У червні жирове тіло бджіл десятиденного віку досягло 2,58 балів розвитку, а до тридцятого дня життя - поступово зменшилося й становило 1,58 балів. Серпневі бджоли, навпаки, від народження до місячного віку накопичували жирове тіло.

\section{БІБЛІОГРАФІЯ}

1. Аветисян Г. А. Пчеловодство. - М. : Колос, 1982. - C. 53-54.

2. Акопян Н. М. Содержание белка в гемолимфе и общего азота в теле зимующих пчел / Н. М. Акопян, О. П. Павленко, С. Г. Асратян // Пчеловодство. - №14. - 1978. - С. 7-8.

3. Домацкая T. Ф. Показатели гемолимфы у пчел при варроатозе // Ветеринария. - 1980. - №11. C. 135.

4. Комлаикий В. И. Структура протеинов гемолимфы пчел / В. И. Комлацкий, С. А. Плотников // Пчеловодство. - №7. - 2004. - С. 23.

5. Лабораторные методы исследования в клинике / под ред. В. В. Меньшикова // М. : Медицина, 1987. - С. $174-175$.
Висновки. Концентрація білка в гемолімфі літніх бджіл від народження по двадцятий день їх життя підвищується, а потім до тридцятого знижується майже до первинного показника; в бджіл передосінньої генерації його кількість із віком не знижується, а залишається на стабільному рівні.

Ступінь розвитку глоткових залоз і жирового тіла бджіл ранньо-літньої генерації із віком знижується, тоді як зимової - залишається стабільним, а жирового тіла - проходить зростання, тобто накопичення в передзимовий період.

6. Лаврехин Р. А. Биология пчелиной семьи / Р. А. Лаврехин, С. В. Панкова. - М. : Колос, 1975. - $296 \mathrm{c}$.

7. Левченко I. В. Вікові відміни за вмістом білка в гемолімфі робочих бджіл / Бджільництво. Вип. 7. - К. : Урожай, 1971. - С. 33-35.

8. Новое в пчеловодстве. - М. : Госсельхозиздат, 1958. - C. 372-388.

9. Таранов Г. Ф. Анатомия и физиология медоносных пчел. - М., 1968. - 344 с.

10. Foti N. Variabilitatea componentului protein din hemolinfa la albine in raport cu virsta, sezonul si activitatea acestora / N. Foti, P. Liviu, L. Crisan // Apicultura (RSR). - 1969. - №8. - C. 11-17. 